\title{
20. DINOFLAGELLATE CYST STRATIGRAPHY OF PALEOCENE TO MIOCENE SEDIMENTS FROM THE GOBAN SPUR (SITES 548-550, LEG 80) ${ }^{1}$
}

\author{
S. Brown, Paleoservices Ltd., Watford \\ and \\ C. Downie, Department of Geology, University of Sheffield ${ }^{2}$
}

\begin{abstract}
Cyst assemblages from Sites 548, 549, and 550 were examined and gave evidence of early Eocene to late Miocene age. These assemblages were compared with other North Atlantic DSDP sites and with onshore sections in Denmark, southern England, Spain, and Italy. Some environmental interpretation is attempted for the Miocene assemblages; pollen, spores, and dinoflagellate cyst species were used to interpret the proximity of the shoreline. Key species are illustrated, along with some forms that are not discussed.
\end{abstract}

\section{INTRODUCTION}

During IPOD Leg 80, four sites were drilled along a transect across the sediment-starved Goban Spur. The transect is $250 \mathrm{~km}$ southwest of Ireland in the northern part of the Bay of Biscay and crosses the continent/ ocean boundary. The post-rift sedimentary cover there is much thinner than on the Amorican margin, since the Goban Spur has remained structurally higher. The principal objectives of Leg 80 were to determine the nature, age, and subsidence history of the continental and oceanic basement near their juncture and to document the age and paleoenvironments of the syn-rift and post-rift sedimentary rocks. The objective of this study is to date the Cenozoic post-rift sediments and to infer their depositional environments.

Samples of Paleocene to Miocene age were processed from Sites 548, 549, and 550, which are at the locations shown in Table 1. All the samples were prepared by using standard palynological techniques and were handled beyond the hydrofluoric acid stage by using the method described by Neves and Dale (1963). The samples processed are listed in Table 2.

Only Hole $548 \mathrm{~A}$ provided samples that contained a good sequence of dinoflagellate cysts; only 10 of the

Table 1. Location of studied sites.

\begin{tabular}{lccc}
\hline Hole & $\begin{array}{c}\text { Latitude } \\
(\mathrm{N})\end{array}$ & $\begin{array}{c}\text { Longitude } \\
(\mathrm{W})\end{array}$ & $\begin{array}{c}\text { Water depth } \\
(\mathrm{m})\end{array}$ \\
\hline 548A & $48^{\circ} 54.93^{\prime}$ & $12^{\circ} 09.87^{\prime}$ & 1251 \\
549 & $49^{\circ} 05.28^{\prime}$ & $13^{\circ} 05.88^{\prime}$ & 2515 \\
$549 \mathrm{~A}$ & $49^{\circ} 05.28^{\prime}$ & $13^{\circ} 05.88^{\prime}$ & 2513 \\
550 & $48^{\circ} 30.91^{\prime}$ & $13^{\circ} 26.37^{\prime}$ & 4420 \\
$550 \mathrm{~B}$ & $48^{\circ} 30.96^{\prime}$ & $13^{\circ} 26.32^{\prime}$ & 4420 \\
\hline
\end{tabular}

\footnotetext{
${ }^{1}$ Graciansky, P. C. de, Poag, C. W., et al., Init. Repts. DSDP, 80: Washington (U. S., Govt. Printing Office).

2 Addresses: (Brown) Paleoservices Ltd., Paramount Industrial Estate, Sandown Rd. Watford, United Kingdom; (Downie) Department of Geology, University of Sheffield, Mappin Street, Sheffield S1 3JD, United Kingdom.
}

samples from the other holes contained dinoflagellates. The remaining samples were barren of palynomorphs. However, most of the samples that contained palynomorphs yielded rich assemblages of dinoflagellate cysts, pollen, and spores. Our ability to use dinocysts to correlate the holes is very limited, unfortunately, since the first appearances of species cannot be defined in the sequences from Holes 549 and 550 .

No attempt was made to zone the range chart (Fig. 1), since no Tertiary dinoflagellate zonation scheme is widely accepted. Rather than construct another zonation, we referred to those of Costa and Downie (1979), Harland (1979), Bujak et al. (1980), and Manum (1976). The large amount of information published on Neogene dinoflagellate cysts in recent years (e.g., Harland, 1977, 1979; Jan du Chêne, 1977; and Piasecki, 1980) has made regional comparison and correlation possible. Species found by these authors to have some stratigraphic significance were used for the relative dating of the samples, and these dates are discussed below in association with the relative dates obtained from the study of the Leg 80 nannoplankton assemblages (Müller, this volume).

The results from Hole 548A are discussed in chronological order. The results from the other, less productive holes are summarized.

\section{HOLE 548A}

\section{Early Eocene}

The early Eocene from Hole 548A is represented by four samples from Sections 26-6 (69-72 cm) to 23-1 (84$85 \mathrm{~cm}$ ). The assemblages present in these samples contain a few diagnostic early Eocene species as well as several with longer ranges. In the presence of Apectodinium quinquelatum, Melitasphaeridium asterium, the Areoligera senonensis complex, Eatonicysta ursulae, Dracodinium condylos, Adnatosphaeridium robustum, and Rhombodinium spp., the assemblage is similar to Ypresian assemblages found in Belgium (De Coninck, 1980) and Zone LC-2 from the London Clay of south- 
Table 2. Samples processed.

\begin{tabular}{|c|c|}
\hline Hole $548 \mathrm{~A}$ & Hole $549 \mathrm{~A}$ (cont.) \\
\hline $2-2,10-12$ & $8-1,60-61^{a}$ \\
\hline $2-4,10-12$ & $9-1,80-81^{a}$ \\
\hline $3-1,74-76$ & $10-1,70-71$ \\
\hline $4-2,80-82$ & $14-1,39-40^{\mathrm{a}}$ \\
\hline $5-1,70-72$ & $16-1,39-40^{\mathrm{a}}$ \\
\hline $6-2,30-34$ & $18-1,39-40^{\mathrm{a}}$ \\
\hline $7-1,50-52$ & $22, \mathrm{CC}, 7-8^{\mathrm{a}}$ \\
\hline $8-1,75-77$ & $24-1,39-40^{\mathrm{a}}$ \\
\hline $9-1,87-88$ & $26-1,80-81^{a}$ \\
\hline $10-3,82-83$ & $27-1,60-61$ \\
\hline $11-1,8-9$ & $28-1,60-61^{a}$ \\
\hline $11-3,8-9$ & $32-1,80-81^{a}$ \\
\hline $11-5,8-9$ & $33-1,70-71^{a}$ \\
\hline $12-1,77-78$ & $34-1,79-80^{\mathrm{a}}$ \\
\hline $13-1,90-92$ & $35-1,32-33^{a}$ \\
\hline $14-1,52-54$ & $36-1,8-9^{a}$ \\
\hline $15-1,118-119$ & $37, \mathrm{CC} 14-15^{\mathrm{a}}$ \\
\hline $16-1,41-42$ & $38-1,55-56^{a}$ \\
\hline $17-1,60-62^{\mathrm{a}}$ & $39-1,100-101^{a}$ \\
\hline $18-1,42-43^{a}$ & $40-1,80-81^{\mathrm{a}}$ \\
\hline $19-1,34-36^{\mathrm{a}}$ & $41-1,1-2^{a}$ \\
\hline $19-5,36-38^{a}$ & $42-1,16-18^{a}$ \\
\hline $20-4,3-5^{a}$ & \\
\hline $21-1,95-96$ & Hole 550 \\
\hline $22-2,97-99^{a}$ & $13-1,75-7^{a}$ \\
\hline $23-1,83-85$ & $\begin{array}{l}13-1,75-7^{a} \\
14-1,103-104^{a}\end{array}$ \\
\hline $24-3,27-29$ & $15-1,64-66$ \\
\hline $25-1,42-43$ & $\begin{array}{l}13-1,04-00 \\
16-1,87-89^{a}\end{array}$ \\
\hline $26-6,69-72$ & $\begin{array}{l}16-1,87-89^{a} \\
17-3,66-68^{a}\end{array}$ \\
\hline $28-7,34-35^{a}$ & $\begin{array}{l}17-3,66-68^{a} \\
18-3,86-88^{a}\end{array}$ \\
\hline $29-1,72-73^{a}$ & $19-1,120-122^{a}$ \\
\hline Hole 549 & $20, C C, 18-19^{a}$ \\
\hline $2-1,36-38$ & $21-1,66-67^{\mathrm{a}}$ \\
\hline $\begin{array}{l}2-1,36-38 \\
3-1,8-10\end{array}$ & $22-1,79-80^{\mathrm{a}}$ \\
\hline $4-1,52-54$ & $\begin{array}{l}23-1,24-25^{\mathrm{a}} \\
24-1,40-44^{\mathrm{a}}\end{array}$ \\
\hline $5-1,72-73$ & $\begin{array}{l}24-1,40-44^{a} \\
24-5,28-29^{a}\end{array}$ \\
\hline $6-1,69-70^{a}$ & $25-5,63-65^{\mathrm{a}}$ \\
\hline $7-1,39-40^{a}$ & $26-1,52-54$ \\
\hline $8-1,80-82^{a}$ & $27-3,53-55^{\mathrm{a}}$ \\
\hline $9-1,41-42^{a}$ & $28-3,57-59^{a}$ \\
\hline $10-1,75-76^{\mathrm{a}}$ & $29-3,58-59^{a}$ \\
\hline $11-1,102-104^{a}$ & $30-3,58-59^{a}$ \\
\hline $12-1,46-48^{\mathrm{a}}$ & $31-1,60-61^{a}$ \\
\hline $13-1,59-61^{a}$ & $32-3,80-81$ \\
\hline $14-1,60-62^{\mathrm{a}}$ & $33-3,66-67^{\mathrm{a}}$ \\
\hline $15-1,62-63^{a}$ & $34-3,68-70^{a}$ \\
\hline $16-1,60-61^{a}$ & $35-3,68-70^{\mathrm{a}}$ \\
\hline $17-1,70-71^{a}$ & $36-1,57-58^{a}$ \\
\hline $18-1,69-70^{\mathrm{a}}$ & $37-1,68-69^{a}$ \\
\hline $19-1,35-36^{a}$ & $38-1,62-63^{a}$ \\
\hline $20-1,72-73^{a}$ & $39-1,82-84^{a}$ \\
\hline $21-2,16-17^{\mathrm{a}}$ & $39-3,85-87^{a}$ \\
\hline Hole 549A & Hole 550B \\
\hline $4-4,34-35$ & $2-1,80-81^{a}$ \\
\hline $5-1,130-131$ & $2-2,77-78^{a}$ \\
\hline $6-1,125-126$ & $2-3,77-78^{a}$ \\
\hline $7-1,120-121^{\mathrm{a}}$ & \\
\hline
\end{tabular}

a Barren of palynomorphs.

ern England (Bujak et al., 1980). The assemblage is impoverished but similar in some respects to the early Eocene Zone II and III assemblages of Costa and Downie (1979) from the Rockall Plateau. Since so few shortranging species are present, it is impossible to give a more accurate correlation with onshore sections. It was assumed that the boundary between the early and middle Eocene occurred in a barren core.

\section{Middle Eocene}

Only one sample of probable middle Eocene age (from Section 21-1, 95-96 cm) produced dinocysts. The nannoplankton in this core are the only evidence that allow the core to be dated (NP15; Müller, this volume), since the dinoflagellate cysts were predominantly Spiniferites ramosus complex, along with Hystrichosphaeropsis obscurum and Impagidinium sp., all species with local ranges that extend beyond this particular sample.

All samples taken from Cores 20 to 17 inclusive were found to be barren.

\section{Late Oligocene}

The late Oligocene is represented by just one sample from Core 16, Section 1. The few dinoflagellates present showed similarities to the late Oligocene Zone VIIa of Costa and Downie (1979) and Zone IIb of Manum (1976); the latter is thought to be of late Oligocene/early Miocene age. The assemblage from the Goban Spur includes Impletosphaeridium sp. I (Manum), Cannosphaeropsis sp. A (Costa and Downie), Operculodinium centrocarpum, and Batiacasphaera baculata.

\section{Early Miocene}

Dinocysts from Cores 15 to 13 inclusive are of early Miocene age. The assemblage from Core 15 contains two typical Oligocene forms that die out in the early Miocene, Distatodinium paradoxum and Apteodinium spiridoides. Several species make their first appearance in Core 15 and continue into the middle and late Miocene. They include Hystrichokolpoma sp. A, Pentadinium laticinctum, Spiniferites mirabilis, cf. Cordosphaeridium minimum, and Achomosphaera crassipellis.

Comparison with other regions is difficult because of the differences in assemblages. The extinction of Distatodinium spp. in the Rockall area (Costa and Downie, 1979) appears to be the only correlatable dinocyst event for the early Miocene. Nematosphaeropsis sp. A occurs with a very restricted range at the end of the early Miocene.

\section{Middle Miocene}

The first appearance of Nematosphaeropsis aquaeducta is considered to be a reliable marker for the early/ middle Miocene boundary (Piasecki, 1980). In Hole $548 \mathrm{~A}$ it appears in Core 12, Section 1, along with "Thalassiphora delicata" (Forma A of Costa and Downie). $N$. aquaeducta was found by Piasecki (1980) in the Hodde Formation of Denmark, where it was dated as middle Miocene, and also by Costa and Downie in the Rockall area, where it marked the base of their Zone VIII. Manum (1976) figured it as Leptodinium sp. V and gave its age as middle Miocene; it marked the base of his Zone Ia. Other species that appear for the first time in the middle Miocene of the Goban Spur are $T u$ berculodinium vancampoae, Melitasphaeridium choanophorum, Tectatodinium psilatum, cf. Pyxidiella scrobiculata, and Polysphaeridium sp. A. (A specimen similar to Polysphaeridium sp. A was figured by Piasecki 


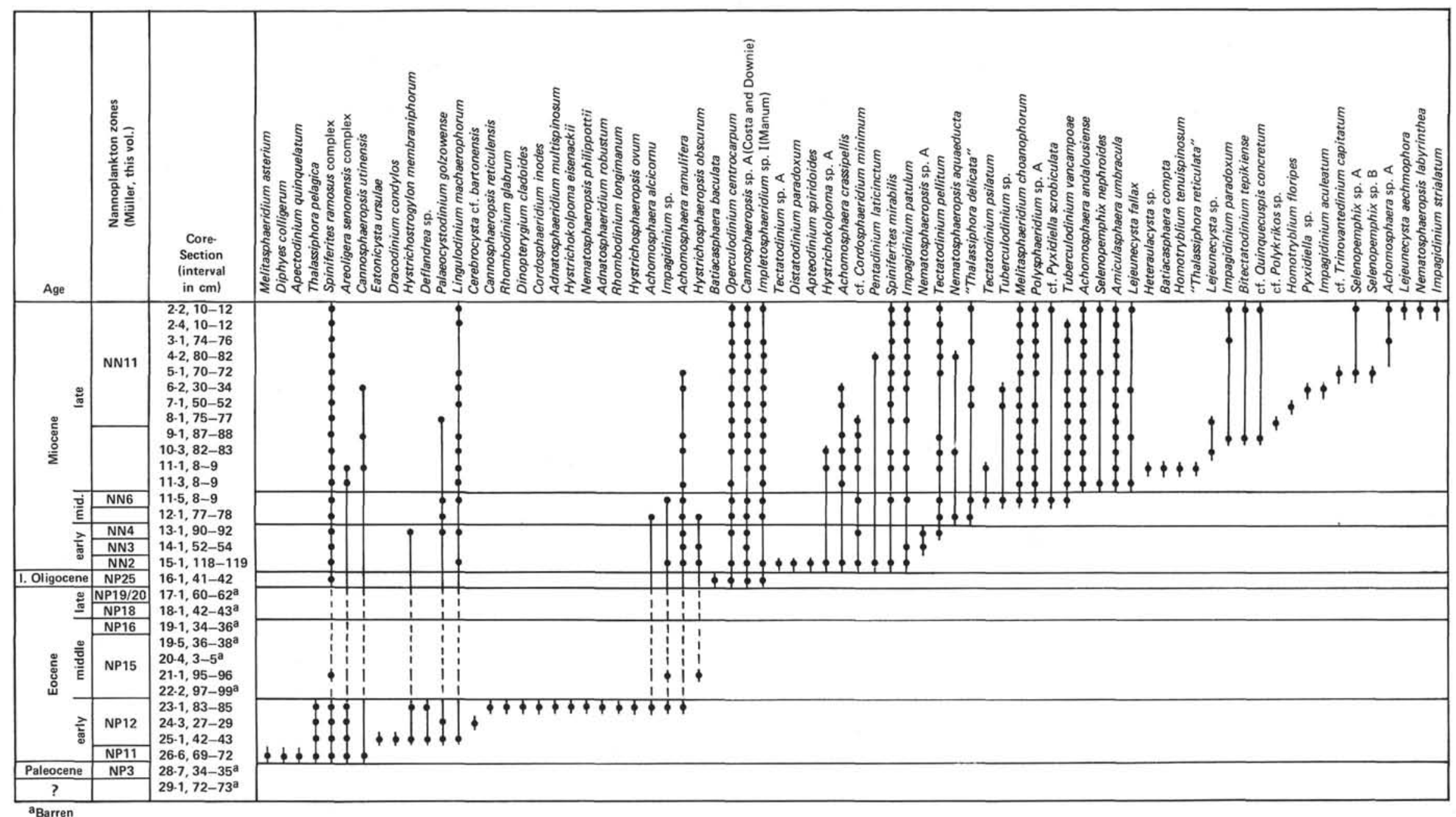

Figure 1. Dinoflagellate cyst stratigraphy of Hole 548A. The assignment of geologic ages is based on the evidence of dinoflagellate cysts and nannoplankton. 
[1980] as cf. Cleistosphaeridium ancoriferum, which had a range throughout the middle and upper Miocene.) The middle Miocene assemblage from the Goban Spur correlates very well with the Danish sequence, and it shows distinct similarities to both the Rockall assemblages from Zone VIII and the Norwegian Sea assemblages from Zone la (Manum, 1976). Some similarity exists with the impoverished middle Miocene assemblage described by Harland (1979) from the Bay of Biscay (DSDP Leg 48).

\section{Late Miocene}

The middle/late Miocene boundary is marked by the first appearance in Section 11-3 (8-9 cm) of Amiculasphaera umbracula, Achomosphaera andalousiense, Lejeunecysta fallax, and Selenopemphix nephroides. Harland (1979) gave the range of Amiculasphaera umbracu$l a$ as late Miocene to early Pleistocene. His quoted range for "Spiniferites septentrionalis" (a junior synonym of Achomosphaera andalousiense) was from middle late Miocene to Pleistocene. A. andalousiense was first described by Jan du Chêne (1977) from the upper Miocene (Andalusian) of southern Spain in an assemblage that has many species in common with the late Miocene assemblages of the present study.

The species composition of the Gram Formation assemblages from Denmark (Piasecki, 1980) is also similar in many ways to that of the late Miocene from the Goban Spur. The first occurrence of $A$. andalousiense at the middle/late Miocene boundary is particularly useful in that it can be correlated with both the present study and that of Harland (1979) from the Bay of Biscay. Harland's late Miocene assemblages are similar in many ways to those of the Goban Spur, but some species that occur in one area are absent from the other.

Other species that occur for the first time in the late Miocene assemblages at Hole 548A are Impadiginium paradoxum, I. strialatum, I. aculeatum, Selenopemphix spp., Bitectadodinium tepikiense, cf. Quinquecuspis concretum, cf. Trinovantedinium capitatum, and Achomosphaera sp. A.

In general, the Miocene sequence from Hole 548A correlates very well with other published data for the European region.

\section{HOLE 549}

Only three samples from Hole 549 contained palynomorphs (those from Sections 2-1, 36-38 cm; 4-1, 52-54 $\mathrm{cm}$; and 5-1, 72-73 cm). The assemblages are dominated by the Spiniferites ramosus complex and contain no species of diagnostic value in dating.

\section{HOLE 549A}

Five samples from Hole 549A produced dinoflagellate cysts. The presence of Nematosphaeropsis aquaeducta, Achomosphaera andalousiense, and Amiculasphaera umbracula suggests that the three productive samples at the top of the hole (in Sections 4-4, 34-35 cm; 5-1, 130$131 \mathrm{~cm}$; and 6-1, 125-126 cm) are of late Miocene age.

Core 10, Section 1, contains a few specimens of an unidentified species of Michrystridium. These are the only palynomorphs present, so they do not allow an age to be given.
Core 27 , Section 1 , is the only other sample that contains dinocysts. However, no diagnostic species were present; only Spiniferites ramosus occurs in this sample.

\section{HOLE 550}

Hole 550 produced two samples that contained dinocysts. The sample from Section 15-1 $(64-66 \mathrm{~cm})$ gave an assemblage that contained Nematosphaeropsis aqueducta, Impagidinium spp., Lingulodinium machaerophorum, Operculodinium centrocarpum, and others that indicated a middle Miocene age. Diagnostic late Miocene species were absent.

The other productive sample was in Section 32-3 (80$81 \mathrm{~cm})$. This sample contained a number of species that indicated an early to middle Eocene age: Dracodinium sp., Lentinia wetzeli, Deflandrea phosphoritica, and Achomosphaera alcicornu.

\section{HOLE 548A: EVIDENCE FROM POLLEN AND SPORES}

The pollen, spores, and dinoflagellates in each sample were counted, and the proximity of land was estimated by comparing the percentage of pollen and spores with the percentage of dinoflagellates. Within the total number of pollen and spores for each sample, the relative percentages of three broad groups (gymnosperm pollen, angiosperm pollen, and pteridophyte spores) were also examined.

The samples from the early Eocene are characterized by high percentages of dinoflagellates; the pollen present is mainly gymnosperm pollen. The percentage of angiosperm pollen and pteridophyte spores is very small. The dominance of windborne gymnosperm pollen indicates a distant shoreline.

The record of pollen and spores from the late Oligocene and Miocene shows that the shoreline was generally quite distant. All the samples contain $80 \%$ or more dinoflagellates, and there are two peaks in the dinocyst values, one in the middle Miocene and one in the late Miocene. These peaks probably represent major marine transgressions when the shoreline became even more distant. This hypothesis is supported by a drop in the percentage of angiosperm pollen and pteriodophyte spores and a rise in the percentage of windborne gymnosperm pollen in the same samples (those from Sections 12-1, $77-78 \mathrm{~cm}$ [middle Miocene] and 6-2, 30-34 cm [upper Miocene]).

\section{ENVIRONMENTAL INDICATIONS FROM MIOCENE DINOCYSTS}

As a result of work by Reid $(1974,1977)$, Harland (1977), and Wall et al. (1977), it has become clear that dominant species in a fossil dinocyst assemblage may be used to infer paleoenvironmental conditions. In the present study only the Miocene dinocyst assemblages are considered, because few modern species are found in Paleogene sediments.

The dominant groups through most of the Miocene at Hole 548A are Spiniferites spp. and Achomosphaera spp. However, during the two transgressive phases inferred from the pollen and spore data outlined above, Operculodinium centrocarpum becomes the dominant 
component of the assemblage. Reid and Harland (1977) indicated that Spiniferites spp. suggested temperate neritic conditions and that $O$. centrocarpum was ubiquitous. However, more recent evidence (R. Harland, pers. comm., 1982) shows that the highest percentages of $O$. centrocarpum in recent sediments are found in the central North Atlantic and Norwegian seas. In the two transgressive phases identified in the present study, $O$. centrocarpum occurs in numbers well above $50 \%$ of the total dinoflagellate cyst population. At the same time, Impagidinium spp. and Nematosphaeropsis aquaeducta, species that have been taken in the past to be indicative of oceanic conditions (Wall et al., 1977), increase in importance.

In the light of this evidence there seems to be little doubt that there were two transgressive phases, one during the early part of the middle Miocene and one in the middle of the late Miocene.

Other genera and species known from modern sediments were recorded from the Miocene of the Goban Spur. For the most part they are considered to be ubiquitous in terms of latitudinal distribution; an exception is Tuberculodinium vancampoae, which is known today only from estuaries in tropical and subtropical areas (Wall et al., 1977). Many estuarine species occurred in small numbers in the assemblages, probably as a result of their being flushed from estuaries during floods.

\section{CONCLUSIONS}

The dinoflagellate cyst assemblages recovered from the Goban Spur show a close similarity, in terms of species composition, to assemblages previously reported from on- and offshore sites in northwestern Europe (i.e., the Rockall Plateau [Costa and Downie, 1979]; the Norwegian Sea [Manum, 1976]; Denmark [Piasecki, 1980]; Belgium [De Coninck, 1980]; southern England [Bujak et al., 1980], the Bay of Biscay [Harland, 1979], and Spain [Jan du Chêne, 1977]). The Miocene of northern Italy also has many species in common with the Miocene of the Goban Spur (Powell, in press). Of particular interest is a new species of Nematosphaeropsis (sp. A in this chapter), which occurs in both areas and becomes extinct at the early/middle Miocene boundary. This species appears to be a good marker for the early Miocene and may have stratigraphic significance in a broader context. Several other new species were found in the present study but occurred in insufficient numbers to warrant description.

\section{ACKNOWLEDGMENTS}

The authors would like to thank Drs. G. L. Eaton and R. Harland for their critical appraisal of the manuscript and the National Science Foundation for providing the samples. Thanks are also due to Dr. A. J. Powell for unpublished information on the Miocene dinoflagellate cysts of Italy.

\section{REFERENCES}

Bujak, J. P., Downie, C., Eaton, G. L., and Williams, G. L., 1980. Dinoflagellate cysts and acritarchs from the Eocene of Southern England. Spec. Pap. Palaeontol., 24.

Costa, L. I., and Downie, C., 1979. Cenozoic dinocyst stratigraphy of Sites 403 to 406 (Rockall Plateau), IPOD, Leg 48. In Montadert, L., Roberts, D. G., et al., Init. Repts. of DSDP, 48: Washington (U.S. Govt. Printing Office), 513-529.

De Coninck, J., 1980. Organic walled microfossils in the clay of Ieper in the Overijse borehole. Bull. Soc. Belge Geol., 89:201-215.

Harland, R. 1977. Recent and Late Quaternary dinoflagellate cysts from marine continental shelf sediments around the British Isles. Palaeontographica, Abt. B, 164:87-126. 1979. Dinoflagellate biostratigraphy of Neogene and Quaternary sediments at Holes $400 / 400 \mathrm{~A}$ in the Bay of Biscay (Deep Sea Drilling Project Leg 48). In Montadert, L., Roberts, D. G., et al., Init. Repts. of DSDP, 48: Washington (U.S. Govt. Printing Office), 531-545.

Jan du Chêne, R., 1977. Étude palynologique du Miocene superieur Andalou (Espagne). Rev. Esp. Micropaleontol., 9:97-113.

Manum, S. B., 1976. Dinocysts in Tertiary Norwegian-Greenland Sea sediments (DSDP Leg 38) with observations on palynomorphs and palynodebris with relation to environment. In Talwani, M., Udintsev, G., et al., Init. Repts. DSDP, 38: Washington (U.S. Govt. Printing Office), 897-919.

Neves, R., and Dale, B., 1963. A modified filtration system for palynological preparations. Nature, 198:775-776.

Piasecki, S., 1980. Dinoflagellate cyst stratigraphy of the Miocene Hodde and Gram Formations, Denmark. Bull. Geol. Soc. Den., 29: $53-76$.

Powell, A. J., in press. Miocene dinoflagellate cysts of the Piedmont Tertiary basin, Italy [Ph.D. dissert.]. University of Sheffield.

Reid, P. C., 1974. Gonyaulacacean dinoflagellate cysts from the British Isles. Nova Hedwigia, 25:579-637. 1977. Peridiniacean and Glenodiniacean dinoflagellate cysts from the British Isles. Nova Hedwigia, 29:429-463.

Reid, P. C., and Harland, R., 1977. Studies of Quaternary dinoflagellate cysts from the North Atlantic. In Elsik, W. C. (Ed.), Contrib. Stratigr. Palynol. (Vol. 1): Am. Assoc. Stratigr. Palynol., Contrib. Ser. No. 5A.

Wall, D., Dale, B., Lohmann, G. P., and Smith, W. K., 1977. The environmental and climatic distribution of dinoflagellate cysts in modern Marine sediments from regions in the North and South Atlantic Oceans and adjacent seas. Mar. Micropalaeontol., 2: 121-200.

Date of Initial Receipt: April 11, 1983

Date of Acceptance: July 8, 1983 

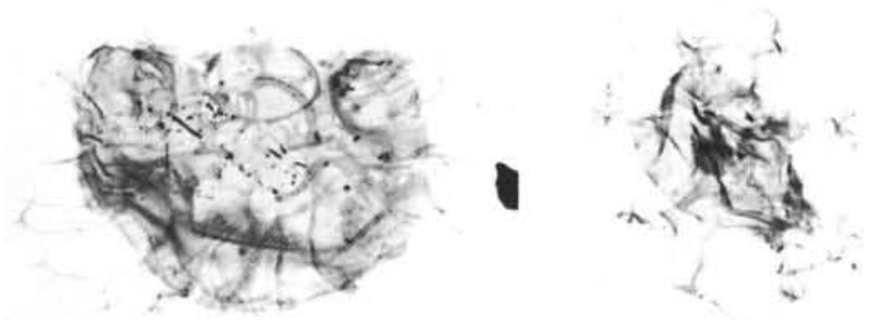

2

1

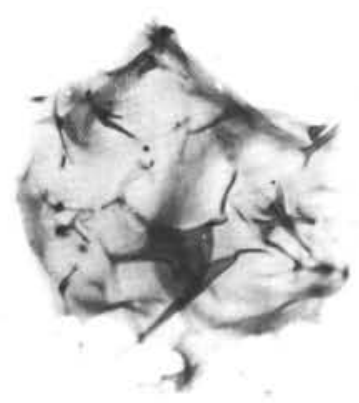

5

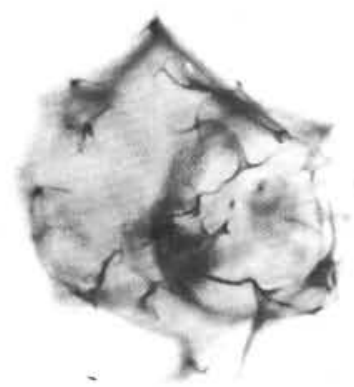

9

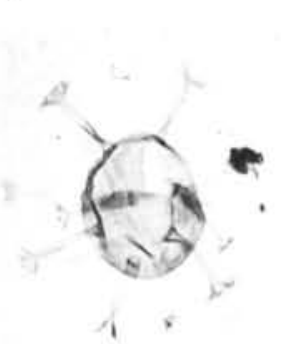

13

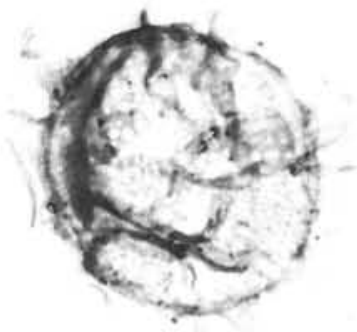

6

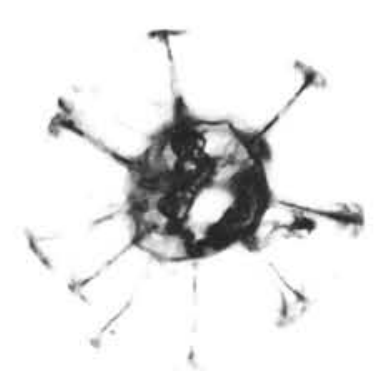

3
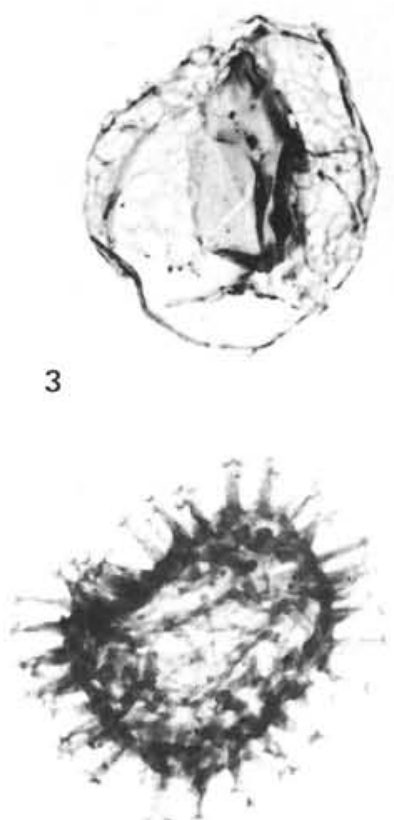

7

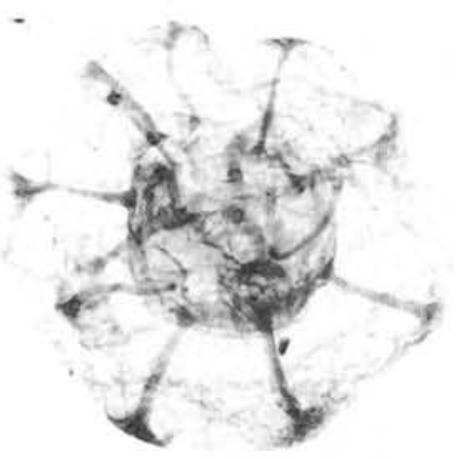

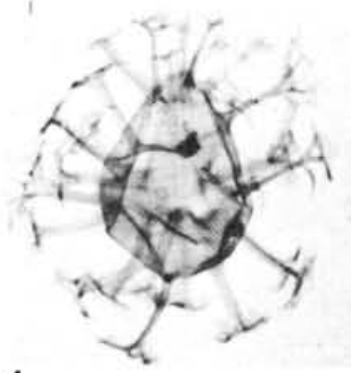

4

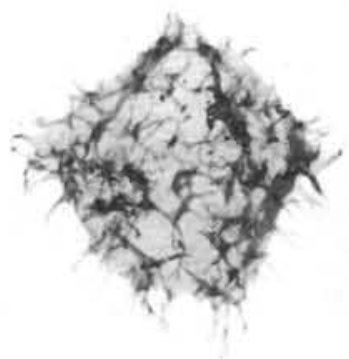

8

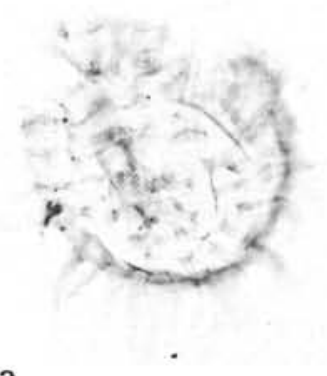

12

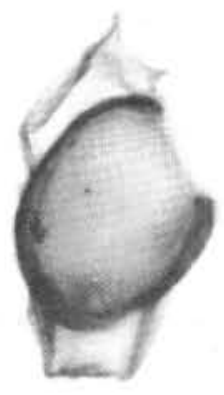

17

Plate 1. All specimens are from Hole 548A and are magnified $\times 500$. Slide numbers and other identifiers are for the England Finder Reference. 1. Areoligera senonensis complex Lejeune-Carpentier; Section 24-3, 27-29 cm; S1, G31/0. 2. Distatodinium paradoxum (Brosius) Eaton; Section 15-1, 118-119 cm; S2, S48/4. 3. Thalassiphora reticulata Morgenroth; Section 11-1, 8-9 cm; S1, Z34/3. 4. Achomosphaera andalousiense Jan du Chêne; Section 9-1, 87-88 cm; S2, F37/1. 5, 9. Hystrichostrogylon membraniphorum Agelopoulos; Section 13-1, 90-92 cm; S3, P29/0. 6. Dinopterygium cladoides Deflandre; Section 23-1, 83-85 cm; S2, Q41/4. 7. Polysphaeridium sp. A; Section 2-2, 10-12 cm; SB, M48/1. 8. Apectodinium quinquelatum (Williams and Downie) Lentin and Williams; Section 26-6, 69-71 cm; S1, U35/2. 10. Melitasphaeridium asterium Eaton; Section 26-6, 69-71 cm; P39/0. 11. Eatonicysta ursulae (Morgenroth) Stover and Evitt; Section 25-1, 42-43 cm; S2, F37/0. 12. Lingulodinium machaerophorum (Deflandre and Cookson) Wall; Section 2-2, 10-12 cm; SB, V35/4. 13. Melitasphaeridium choanophorum (Deflandre and Cookson) Harland and Hill; Section 9-1, 87-88 cm; S4, M35/0. 14. Apteodinium spiridoides Benedek; Section 15-1, 118-119 cm; S1, V46/4. 15. Achomosphaera ramulifera (Deflandre) Evitt; Section 11-3, 8-9 cm; S2, L43/4. 16. Impletosphaeridium sp. I (Manum); Section 15-1, 118-119 cm; S2, T38/3. 17. Hystrichosphaeropsis ovum Deflandre; Section 23-1, 83-85 cm; S2, V39/0. 


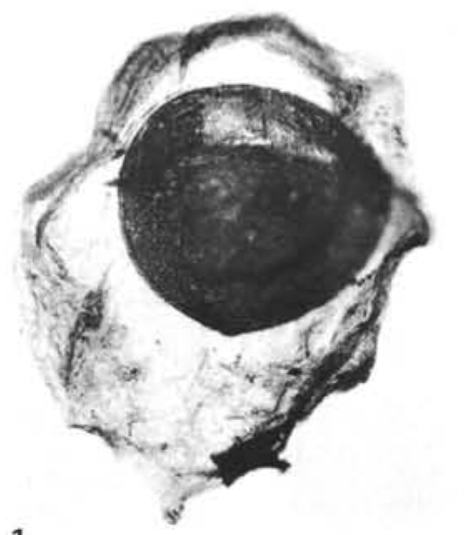

1

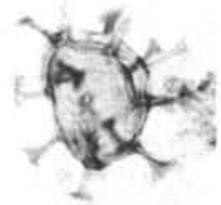

6

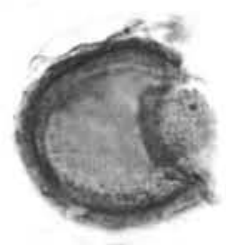

12

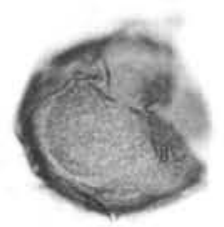

18

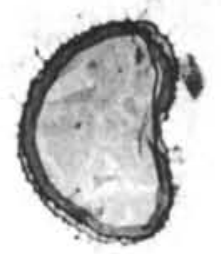

20

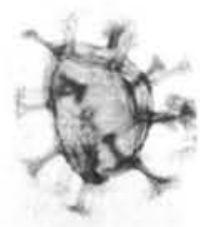

7

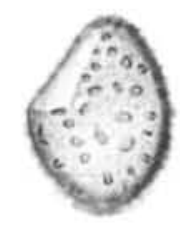

13

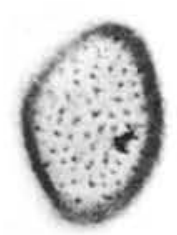

19

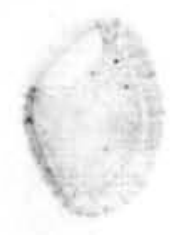

21

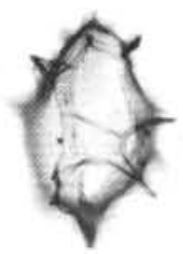

2

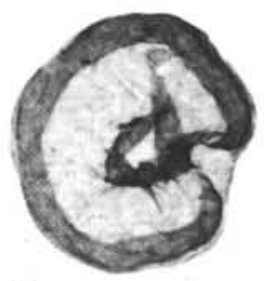

8

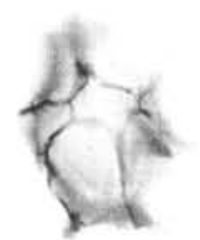

3

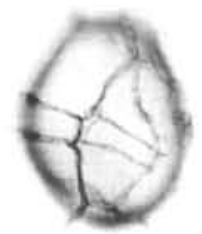

9

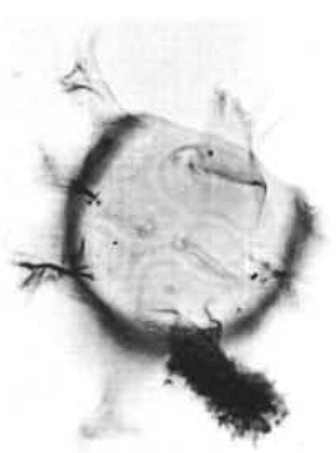

14

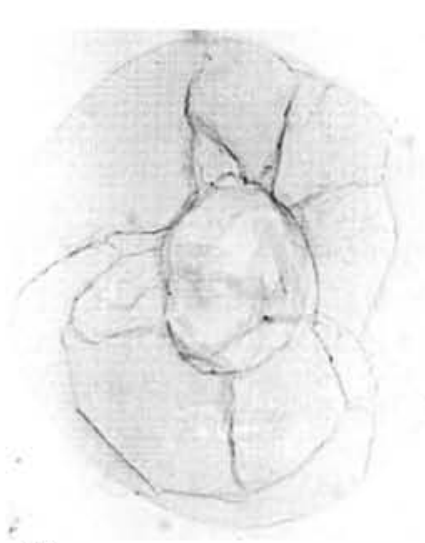

22

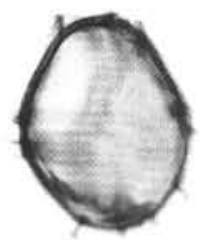

4

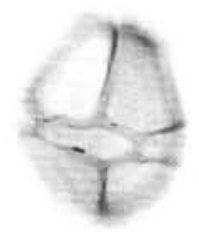

10

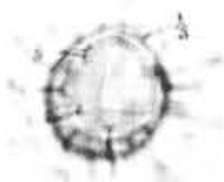

15

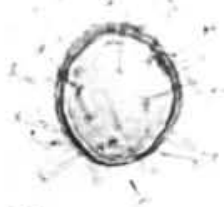

16

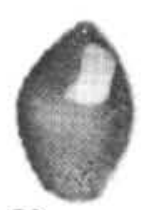

23

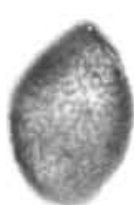

24

25

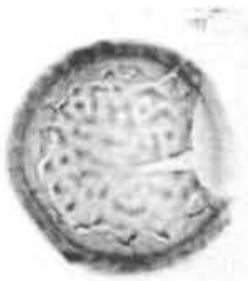

5

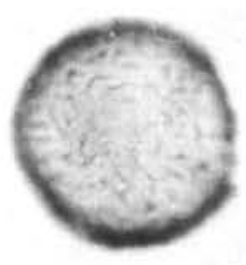

11

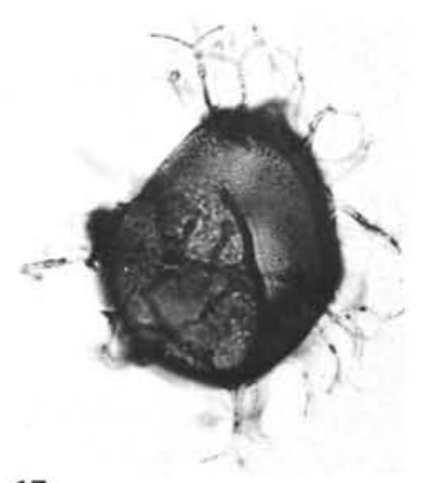

17

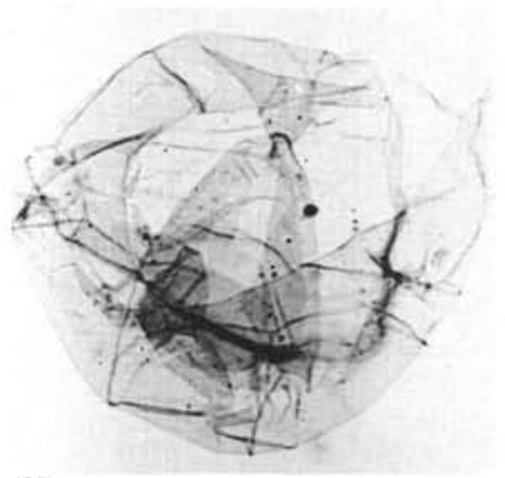

Plate 2. All specimens are from Hole 548A and are magnified $\times 500$ unless stated otherwise. Slide numbers and other identifiers are for the England Finder Reference. 1. Thalassiphora pelagica (Eisenack) Eisenack and Gocht ( $\times 350$ ); Section 25-1, 42-43 cm; S2, N29/2. 2, 3. Impagidinium aculeatum (Wall) Stover and Evitt; Section 4-2, 80-82 cm; S2, L31/0. 4, 9, 10. Impagidinium cf. paradoxum (Wall) Stover and Evitt; Section 15-1, 118-119 cm; S4, L37/2. 5, 11. Cerebrocysta bartonensis Bujak et al.; Section 24-3, 27-29 cm; S1, U47/0. 6, 7. cf. Cordosphaeridium minimum (Morgenroth) Benedek; Section 15-1, 118-119 cm. 8. Cyst of Protoperidinium sp. indet.; Section 2-2, 10-12 cm; S1, H34/0. 12, 18. Pentadinium laticinctum Gerlach; Section 15-1, 118-119 cm; S3, E42/2. 13. cf. Pyxidiella sp.; Section 2-2, 10-12 cm; SB, $\mathrm{T} 49 / 4$. 14. Hystrichokolpoma sp.; Section $15-1,118-119 \mathrm{~cm} ; \mathrm{S} 4, \mathrm{E} 39 / 0 . \quad 15,16$. Melitasphaeridium cf. pseudorecurvatum; Section 2-2, 10$12 \mathrm{~cm}$; SB, T56/3. 17. Achomosphaera sagena Davey and Williams; Section 2-2, 10-12 cm; SC, P38/3. 19, 21. Pyxidiella cf. scrobiculata (Deflandre and Cookson) Cookson and Eisenack; Section 7-1, 50-52 cm; S1, P35/0. 20. Selenopemphix sp. A; Section 2-2, 10-12 cm; E50/

1. 22. "Thalassiphora delicata" Williams and Downie; Section 2-2, 10-12 cm; SB, L46/4. 23, 24. cf. Pyxidiella sp.; Section 2-2, 10-12 cm; S3, E55/2. 25. Amiculosphaera umbracula Harland; Section 2-2, 10-12 cm; SC, P57/3. 

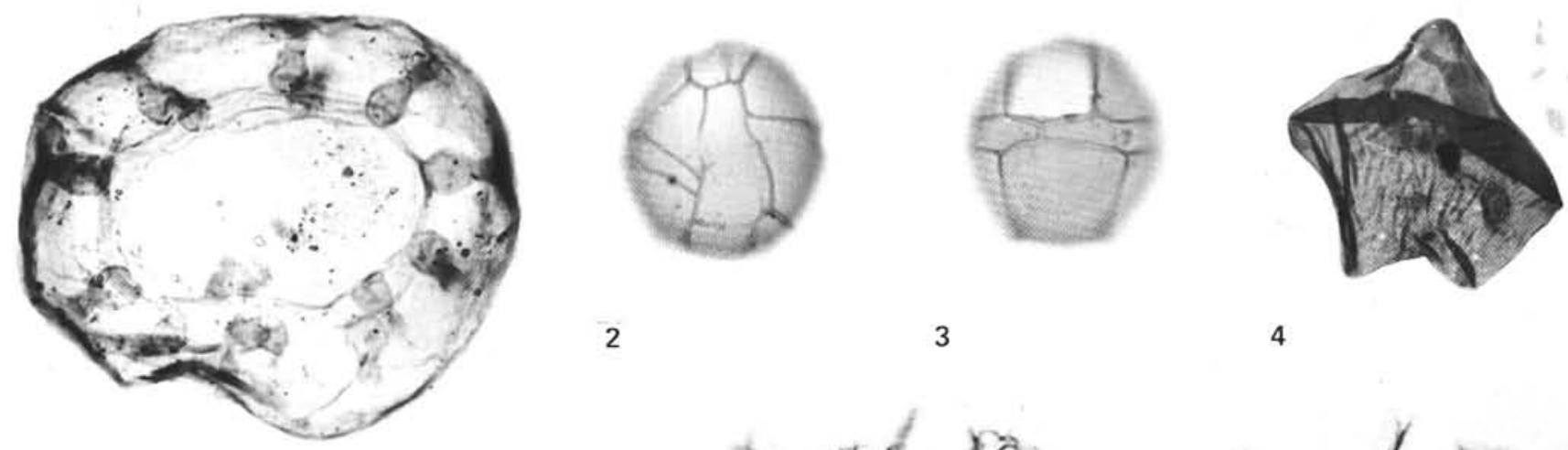

2

3

4

1

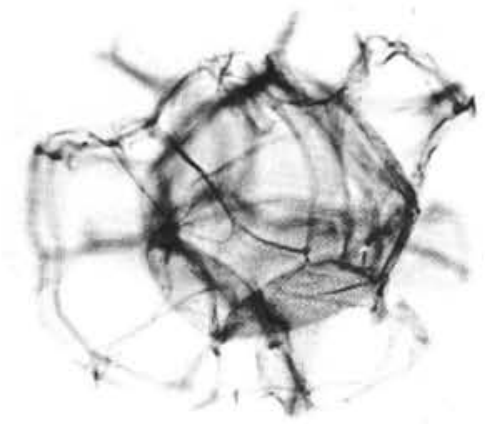

7

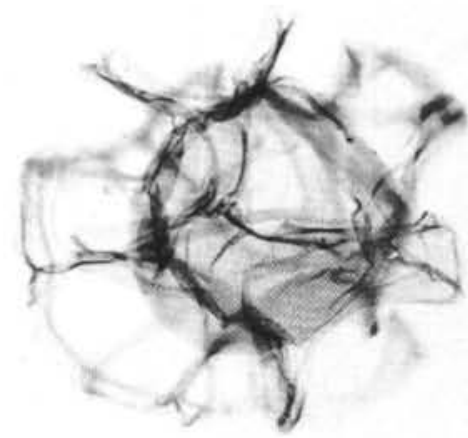

6

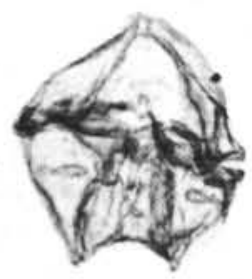

8

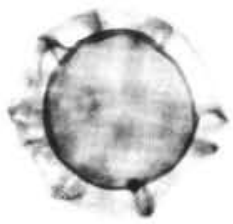

9

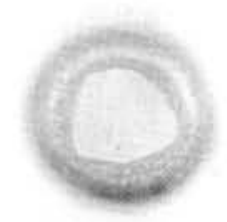

10

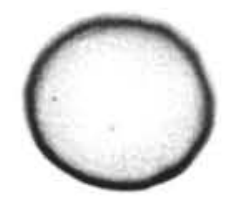

11

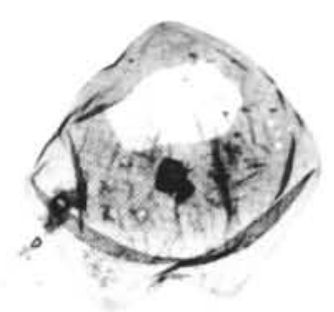

12
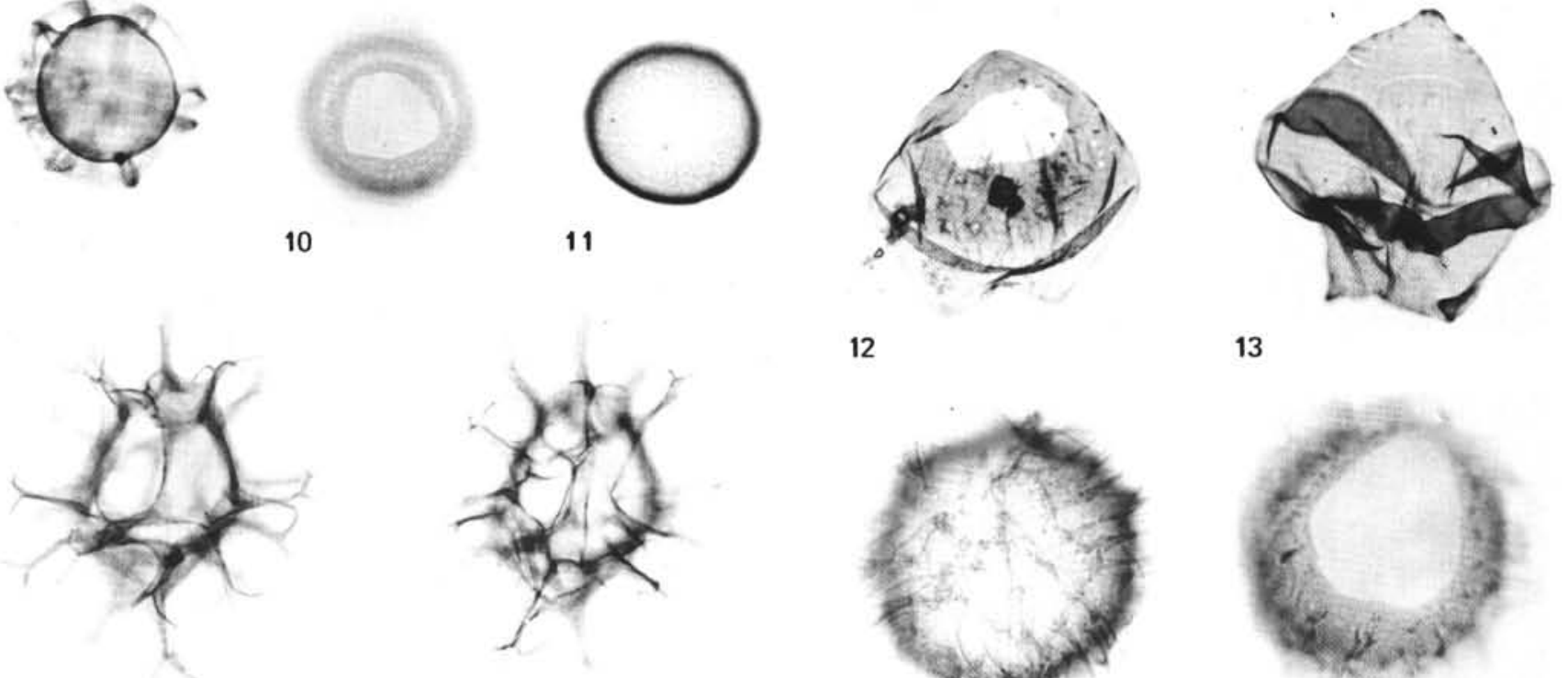

13
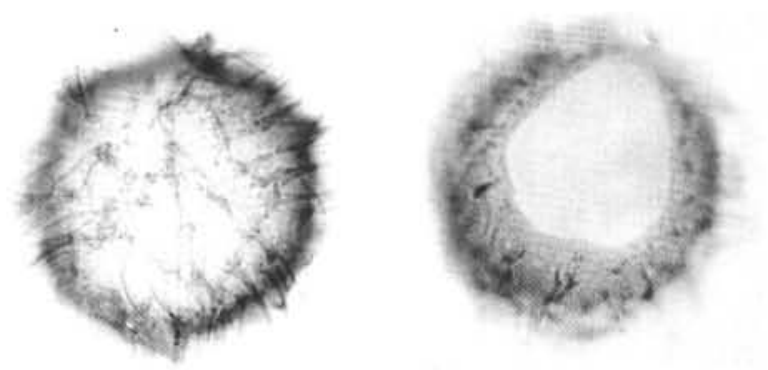

17

14

15

16

Plate 3. All specimens are from Hole 548A (unless stated otherwise) and are magnified $\times 500$. Slide numbers and other identifiers are for the England Finder Reference. 1. Tuberculodinium vancampoae (Rosignol) Wall emend. Wall and Dale; Section $11-3,8-9 \mathrm{~cm} ; \mathrm{S} 2, \mathrm{P} 35 / 1$. 2, 3. Impagidinium patulum (Wall) Stover and Evitt; Section 4-2, 80-82 cm; S3, T37/1. 4. cf. Quinquecuspis concretum Harland; Section 9-1, 87-88, cm; S4, J41/0. 5, 9. Nematosphaeropsis aquaeducta Piasecki; Hole 549A; Section 6-1, 125-126 cm; S1, P47/0. 6. Lejeunia fallax Morgenroth; Section 9-1, 87-88 cm; S4, E42/0. 7, 8. Nematosphaeropsis sp. A; Section 14-1, 52-54 cm; S2, U32/1. 10, 11. Tectatodinium pellitum Wall; Section 2-2, 10-12 cm; SB, X42/0. 12. cf. Quinquecuspic concretum Harland, Section 9-1, 87-88 cm; S2, J36/2. 13. Protoperidinoid cyst gen. et sp. indet.; Section 11-3, 8-9 cm; S2, N40/0. 14, 15. Spiniferites ramosus (Ehrenberg) Loeblich and Loeblich; Section 14-1, 52-54 cm; $\mathrm{S} 1, \mathrm{~N} 30 / 0.16,17$. Operculodinium centrocarpum (Deflandre and Cookson) Wall; Section 2-2, 10-12 cm; SB, N56/2. 


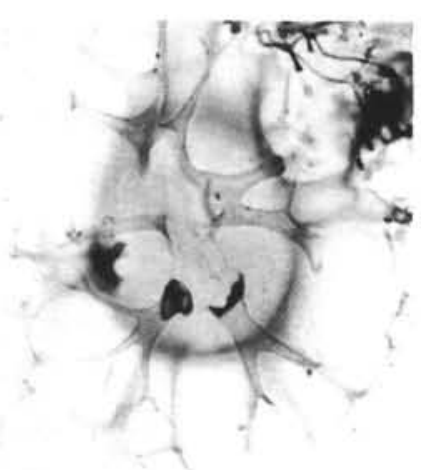

1

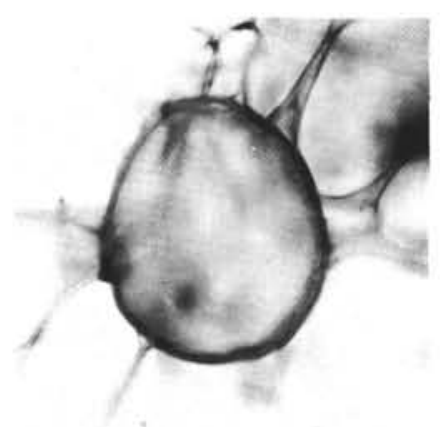

5

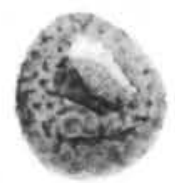

9

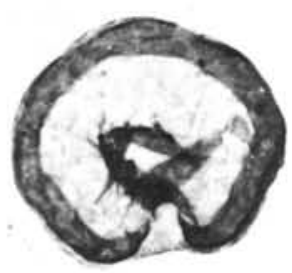

13

10

14

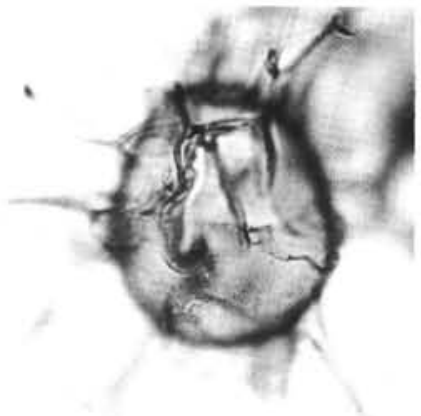

2

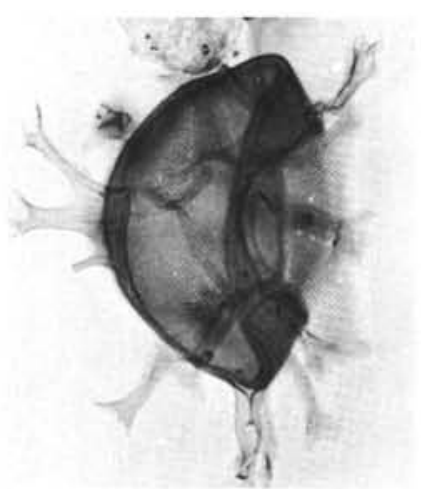

6
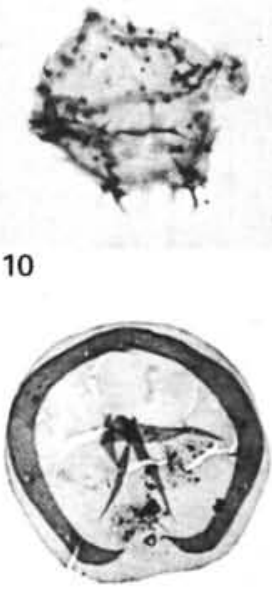
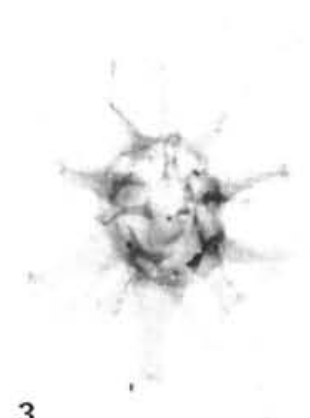

3
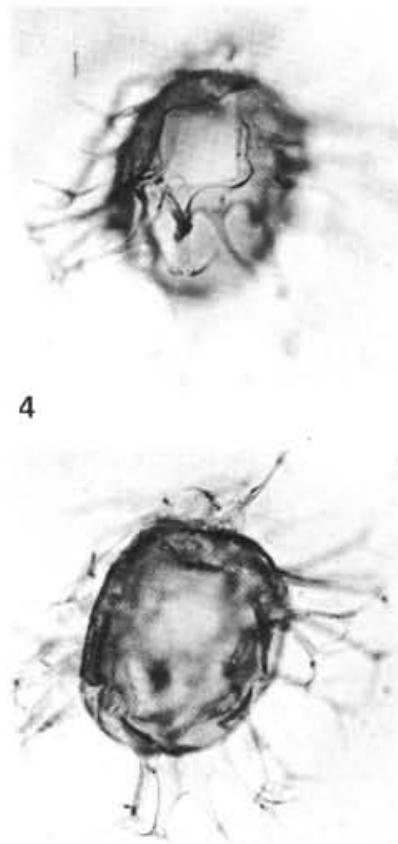

8

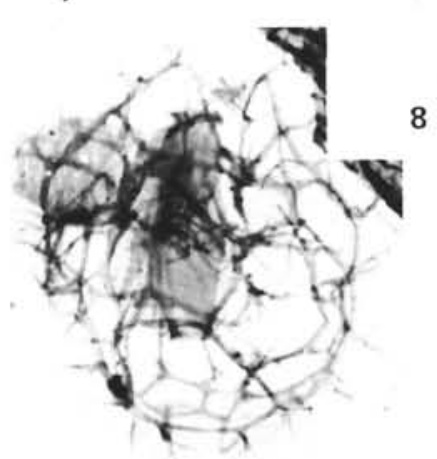

II

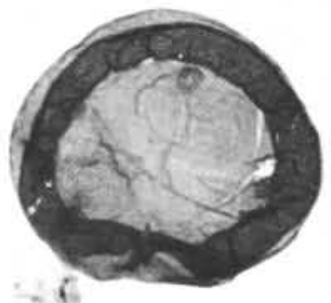

12

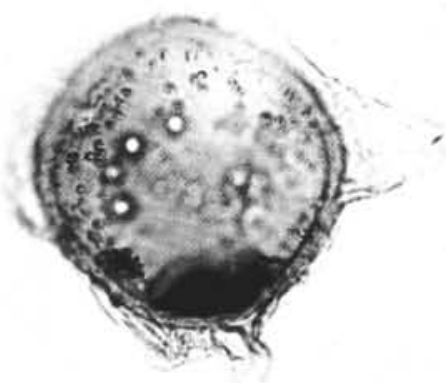

15

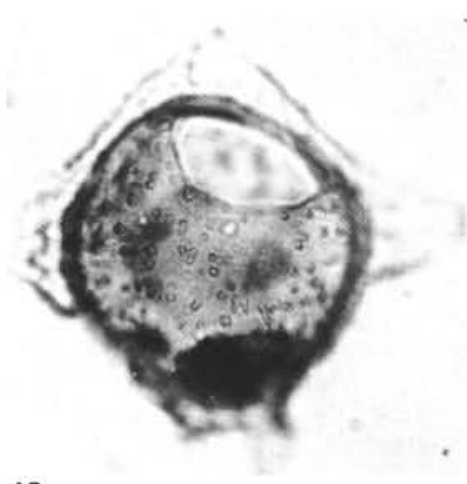

16

Plate 4. All specimens are from Hole $548 \mathrm{~A}$ and are magnified $\times 500$. Slide numbers and other identifiers are for the England Finder Reference. 1, 2, 5. Achomosphaera sp. A; Section 2-2, 10-12 cm; SB, M54/0. 3. Hystrichokolpoma sp. A; Section 14-1, 52-54 cm; S1, N33/0. 4, 8. Spiniferites mirabilis (Rossignol) Sarjeant; Section 2-2, 10-12 cm; SB, M40/3. 6. Spiniferites pseudofurcatus (Klumpp) Sarjeant; Section 14-1, 52-54 cm; S1, L30/0. 7. Cannosphaeropsis sp. A (Costa and Downie); Section 15-1, 118-119 cm; 53, 033/1. 9. Gen. et sp. indet.; Section 14-1, 52-54 cm; S1, H34/0. 10. Gen. et sp. indet.; Section 11-3, 8-9 cm; S1, L44/0. 11. Cannosphaeropsis utinensis Wetzel; Section 5-1, $70-72 \mathrm{~cm} ; \mathrm{S} 1, \mathrm{~J} 32 / 0$. 12. Selenopemphix nephroides Benedek; Section 5-1, 70-72 cm; S1, M32/3. 13. Cyst of Protoperidium sp. indet.; Section 11-3, 8-9 cm; S2, H35/4. 14. Selenopemphix nephroides Benedek; Section 2-2, 10-12 cm; SB, L45/1. 15, 16. Dracodinium condylos (Williams and Downie) Bujak et al.; Section 25-1, $42-43 \mathrm{~cm}$; S3, H47/1. 